\title{
Use of indigenous language for clinical clerkship: a cross-sectional survey in Nigeria
}

\author{
Oyebanji Olajuyin, ${ }^{1}$ Oladele Olatunya, ${ }^{2}$ Toye Olajide, ${ }^{3}$ Ademola Olajuyin, ${ }^{4}$ Adebola Olajuyin, ${ }^{5}$ Femi. Ogunboyo ${ }^{6}$ and Kehinde Oluwadiya ${ }^{7}$
}

${ }^{1}$ Department of Ear, Nose and Throat, Ekiti State University Teaching Hospital, Ado Ekiti, Nigeria. ${ }^{2}$ Department of Paediatrics, Ekiti State University Teaching Hospital, Ado Ekiti, Nigeria. ${ }^{3}$ Department of Ear, Nose and Throat, Federal Teaching Hospital, Ido Ekiti and Afe Babalola University, Ado Ekiti, Nigeria. ${ }^{4}$ Department of Family Medicine, Ekiti State University Teaching Hospital, Ado Ekiti, Nigeria. ${ }^{5}$ Department of Obstetrics-Gynaecology, Ekiti State University Teaching Hospital, Ado Ekiti, Nigeria. ${ }^{6}$ Department of Statistics, Faculty of Science, Ekiti State University, Ado Ekiti, Nigeria. ${ }^{7}$ Department of Surgery, Ekiti State University Teaching Hospital, Ado Ekiti, Nigeria. (Correspondence to: Oyebanji Olajuyin: oyebanjiolajuyin@yahoo.com).

\begin{abstract}
Background: Doctors' knowledge of the native language of their patients is important to effectively communicate with them.

Aims: This paper aimed to explore the views and practices of medical students in Nigeria on the use of Yorùbá (an indigenous language) in their clinical clerkship.

Methods: This was a cross-sectional survey of students in two medical colleges in Ekiti State, Nigeria. Data were collected using self-administered questionnaires.

Results: The study included 312 medical students, 176 males and 136 females. Most students (70.8\%) used Yorùbá in their clinical clerkship despite learning medicine in English. Only 16.0\% of the students relied on interpreters. None of the students had had exposure to language training in the course of their medical education. Most of the students (73.7\%) supported the incorporation of indigenous language training into the medical school curriculum, and agreed that teaching indigenous languages in medical school would enhance communication skills.
\end{abstract}

Conclusions: Incorporation of indigenous language training into the medical school curriculum in Nigeria is recommended to help overcome language barriers in clinical practice.

Keywords: medical education, clinical clerkship, language, communication barriers, Nigeria, indigenous

Citation: Olajuyin O; Olatunya O; Olajide T; Olajuyin A; Olajuyin A; Ogunboyo F; et al. Use of indigenous language for clinical clerkship: a cross-sectional survey in Nigeria. East Mediterr Health J. 2022; 28(2):158-162. https://doi.org/10.26719/emhj.22.029

Received: 17/03/21; accepted: 15/06/21

Copyright (C) World Health Organization (WHO) 2022. Open Access. Some rights reserved. This work is available under the CC BY-NC-SA 3.0 IGO license (https://creativecommons.org/licenses/by-nc-sa/3.o/igo).

\section{Introduction}

Given the global trend in patient-centred medical education, the need for students to acquire communication skills in the local language cannot be overemphasized (1). Patients need to perceive that the doctor is interested in knowing them by understanding their backgrounds, including their culture and language. (2). Indeed, "the most basic need of a person seeking health care is the need to be heard and understood" (3). In 2018, the Nigerian Consumer Protection Council enacted the patient's bill of rights, which stipulates that: "Access to all relevant information including diagnosis, treatment, prognosis and procedures must be provided in a language that the patient understands" (4). Because of this, medical students and physicians should be trained to become aware of the importance of the cultural background of patients (5) and language (6). In fact, if language is a vital tool of communication, if communication is a carrier of culture and if culture and disease are closely related, then the role of language in disease management cannot be overemphasized.

Recognizing the need to improve the use of indigenous language in medical communication, scholars have recommended a review of medical school curricula to incorporate languages other than English $(7,8)$. Although research into the promotion of indigenous language among health care practitioners has been undertaken in many places, there has been little interest in this issue in developing countries, especially in Nigeria. While the cultural competence of doctors has attracted attention, the issue of indigenous language competence among doctors has largely been ignored (3,9). Little research has been published on indigenous language proficiency in other health care training programmes and language tuition for medical students $(3,9)$.

This study therefore aimed to explore the views of medical students in Nigeria on the use of Yorùbá (the indigenous language) in their clinical clerkship.

\section{Methods}

This was a prospective, cross-sectional survey of students in two medical colleges in Ekiti State, Nigeria, conducted in April 2019. Ekiti State has a population of more than 2 million people (10) and the main occupation in the state is farming. Thus, most people are rural dwellers and speak Yorubá, the indigenous language and the main language of communication. We recruited medical students in their clinical years using a convenience sam- 
pling technique. The students were invited through their class supervisors. We explained the purpose of the study and only those who gave informed consent to participate were included. Refusal of any student to participate did not in any way interfere with their training. We did not give any monetary or other remuneration for participating in the study.

Data were collected using validated, self-administered questionnaires in English consisting of open-ended, categorical and ranking items on Likert scale. The questionnaires were completed in person and were returned immediately to the supervisors.

\section{Results}

We approached 338 students, 16 (5\%) declined to participate. Of the 322 students who agreed to participate, 10 submitted incomplete questionnaires. Thus 312 students were included in the final analysis (92\% total response rate): 176 were males and 136 were females (male:female ratio 1.3:1). Their ages ranged from 20 to 36 years with the eldest in their final year. More than half of the participants $(53.8 \%)$ were Yorùbá, therefore, Yorùbá was their mother tongue. None of the students had had exposure to language courses during their medical education. Of the 312 respondents, $221(70.8 \%)$ understood Yorùbá very well and used it in their clinical clerkship. Only 50 (16.0\%) of the students relied on interpreters for the clinical clerkship.

The responses of the participants to the benefits of using the indigenous language and their support for its inclusion in the medical curriculum are shown in Table 1 and Figure 1. Most students (69.6\%) thought clinical clerkship in the native language could enhance diagnostic accuracy and help patients and their families understand diagnosis and treatment. Most also supported the incorporation of a year-long indigenous language course into the pre-basic Bachelor of Medicine and Bachelor of Surgery (MBBS) programme for effective clinical communication (73.7\%). A large majority of the students (92.3\%) considered multilingual nature of Nigeria a threat to the inclusion of indigenous languages in the medical school curriculum.

\section{Discussion}

This study shows that $70.8 \%$ of the medical students used the Yorubá language for clinical clerkship despite learning medicine in a foreign language. The finding concurs with a study of students in Lebanese medical schools, $88.5 \%$ of whom were confident to conduct medical history in their native language (Arabic), despite having their medical education in a foreign language (either English or French) (11). Our finding also agrees with a study in Egypt which reported that $70.6 \%$ of medical students in their clinical years would prefer to learn patient history-taking in Arabic (12).

In our study, none of the students had had any indigenous language training. Thus, the Yorùbá language that they use for clinical clerkship was learned informally and this may not be adequate for effective communication in a clinical setting. Most of the students expressed interest in improving their knowledge of the indigenous language. Thus, there is the need for language tuition for medical students with a view to improving their competence in clinical communication. Some (16.0\%) of

Table 1 Students' views on the benefits of, support for and barriers to the use of indigenous languages in clinical practice, Nigeria, 2019

\begin{tabular}{|c|c|c|c|c|c|}
\hline \multirow[t]{2}{*}{ Item } & \multicolumn{5}{|c|}{ No. $(\%)(n=312)$} \\
\hline & Strongly agree & Agree & Undecided & Disagree & $\begin{array}{l}\text { Strongly } \\
\text { disagree }\end{array}$ \\
\hline $\begin{array}{l}\text { Knowledge of indigenous language } \\
\text { among medical students could promote } \\
\text { language concordance between patients } \\
\text { and students }\end{array}$ & $142(45.5)$ & $124(39.7)$ & $40(12.8)$ & $4(1.3)$ & $2(0.6)$ \\
\hline $\begin{array}{l}\text { Clinical clerkship in the native language } \\
\text { could enhance diagnostic accuracy } \\
\text { and help patients and their families to } \\
\text { understand diagnosis and treatment }\end{array}$ & $185(59.3)$ & $32(10.3)$ & $65(20.8)$ & $11(3.5)$ & $19(6.1)$ \\
\hline $\begin{array}{l}\text { Use of indigenous language could save } \\
\text { physicians from unnecessary litigation }\end{array}$ & $72(23.1)$ & $103(33.0)$ & $87(27.9)$ & $41(13.1)$ & $9(2.9)$ \\
\hline $\begin{array}{l}\text { Use of indigenous language instead of an } \\
\text { interpreter for clinical clerkship during } \\
\text { MBBS examination could save time }\end{array}$ & $104(33.3)$ & $140(44.9)$ & $38(12.2)$ & $20(6.4)$ & $10(3.2)$ \\
\hline $\begin{array}{l}\text { I support the incorporation of a year } \\
\text { course in indigenous language into the } \\
\text { pre-basic MBBS programme for effective } \\
\text { clinical communication }\end{array}$ & $69(22.1)$ & $161(51.6)$ & $59(18.9)$ & $10(3.2)$ & $13(4.2)$ \\
\hline $\begin{array}{l}\text { Multilingualism is a potential barrier to } \\
\text { the inclusion of indigenous language into } \\
\text { the medical school curriculum }\end{array}$ & $81(26)$ & $207(66.3)$ & $\mathrm{o}(\mathrm{o})$ & $20(6.4)$ & $4(1.3)$ \\
\hline
\end{tabular}


Figure 1 Students' views on the benefits of the use of indigenous languages in clinical practice, Nigeria, 2019

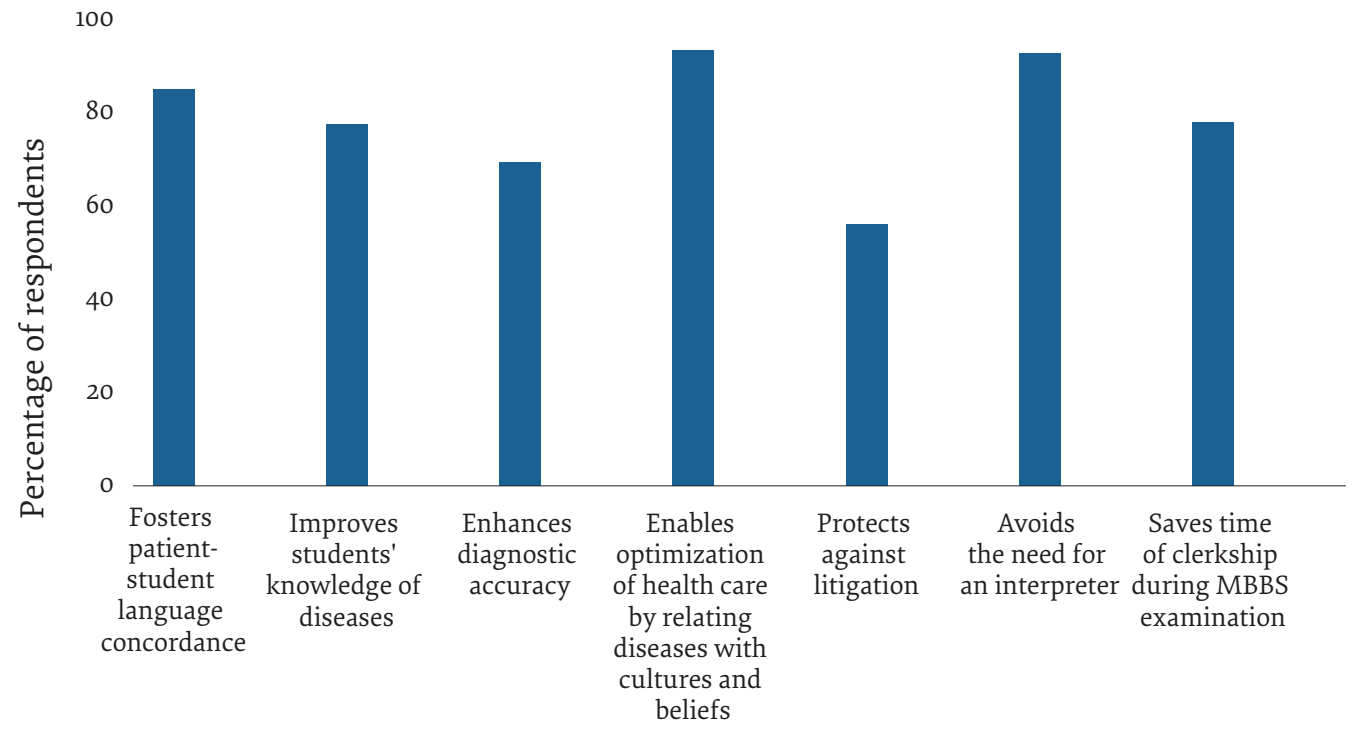

the participants depended on interpreters for their clinical clerkship and such practice was considered contrary to good-quality health care by most of our participants. Patients who communicated through an interpreter rated their provider as less friendly, less respectful, less concerned for the patient as a person, and less likely to make the patient comfortable (13). These findings support the need for language tuition to ensure consistency of communication between patients and students.

Our participants considered there were several values of language tuition for medical students. They agreed that it could enhance health care delivery. Some $56.1 \%$ of the participants thought that the use of the indigenous language in clinical communication could protect physicians from litigation. They thought speaking directly with patients instead of through an interpreter could save time during the MBBS examination. Other researchers have reported on the benefits of clinical communication in the language that the patient understands $(14,15)$. In a study of medical students' perception of the usefulness of additional language tuition in the University Cape Town medical school programme, the vast majority of the students believed that learning Xhosa and/or Afrikaans was valuable (9). These values underscore the need for the incorporation of language training in the curriculum of medical schools where such training does not exist. The training may be introduced during the pre-basic year of the students' medical education. It has been suggested that students should consider learning other languages before the demands of medical school make additional learning more challenging (14). A recent paper stated: "While learning a new language may be the last thing you want to add to your plate as a medical student, the fact is that doing so can help you not only learn better, but also to apply that learning in the most effective way. The old doctor spoke Latin, the new doctor speaks English, the good doctor speaks to the patient and the more directly you're able to communicate with patients, the more successful you'll be from a patient care perspective" (1).

The vast majority of our respondents considered that multilingual nature of Nigeria was a potential barrier to nationwide incorporation of the indigenous language into the medical school curriculum. This finding contrasts sharply with the opinion of others who argue that the important thing is for health care professionals to learn a set of communication skills so they can work effectively in the communities they serve (3). In a multilingual South Africa with 11 official languages, all health sciences students learn Afrikaans and Xhosa at the University of Cape Town (3). This attests to the feasibility of learning medicine in a foreign language while learning communication in an indigenous language in a multilingual society. All that is required is a modification of the curriculum. Thus, prospective candidates seeking admission to study medicine should be made to understand the need to study the indigenous language of the area where the medical school they wish to attend is situated.

Funding: None.

Competing interests: None declared. 


\section{Utilisation de la langue autochtone dans le cadre des stages cliniques : une enquête transversale au Nigéria}

\section{Résumé}

Contexte: Il est important que les médecins maîtrisent la langue maternelle de leurs patients pour pouvoir communiquer avec eux de manière efficace.

Objectifs : Le présent article visait à examiner les opinions et les pratiques des étudiants en médecine au Nigéria concernant l'utilisation du Yoruba (la langue autochtone) dans le cadre de leur stage clinique.

Méthodes: Il s'agissait d'une enquête transversale auprès d'étudiants de deux facultés de médecine de l'État d'Ekiti (Nigéria). Les données ont été recueillies au moyen de questionnaires auto-administrés.

Résultats : L'étude a porté sur 312 étudiants en médecine, dont 176 hommes et 136 femmes. La plupart des étudiants $(70,8 \%)$ utilisaient le Yoruba durant leur stage clinique, alors que la médecine leur était enseignée en anglais. Seuls $16,0 \%$ des étudiants avaient recours à des interprètes. Aucun des étudiants n'avait bénéficié de cours de langue durant son cursus médical. La plupart des étudiants $(73,7 \%)$ étaient favorables à l'intégration d'une formation en langue autochtone dans le programme des études de médecine. Ils ont convenu que l'enseignement des langues autochtones dans les facultés de médecine permettrait d'améliorer les compétences de communication.

Conclusions: L'intégration d'une formation en langue autochtone dans le programme d'études des facultés de médecine au Nigéria est recommandée afin de surmonter toute barrière linguistique dans la pratique clinique.

$$
\begin{aligned}
& \text { استخدام لغة الشعوب الأصلية في التدريب السريري، نيجيريا: دراسة مقطعية }
\end{aligned}
$$

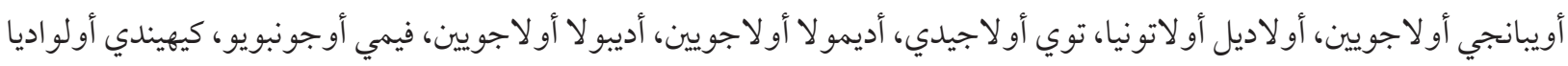

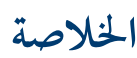

$$
\begin{aligned}
& \text { الخلفية: من المهم أن يعرف الأطباء اللغة الأم لمرضاهم من أجل التو اصل معهم بفعالية. }
\end{aligned}
$$

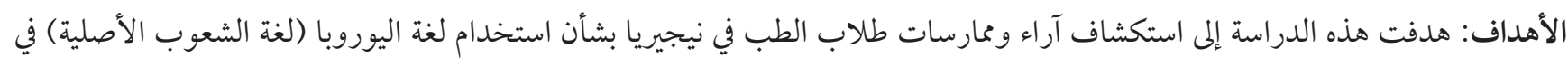

$$
\begin{aligned}
& \text { تلدريبهم السريري. } \\
& \text { طرق البحث: أجريت دراسة مقطعية على طلاب كليتين للطب في ولاية إيكيتي. وجمعت البيانات من خلال استبيانات يملؤها المستجيبون بأنفسهم. }
\end{aligned}
$$

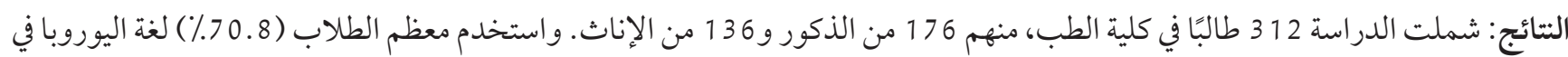

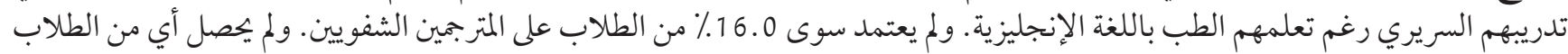

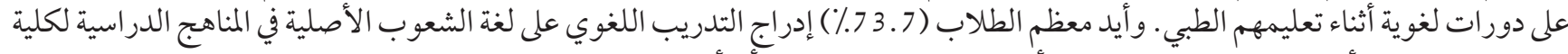

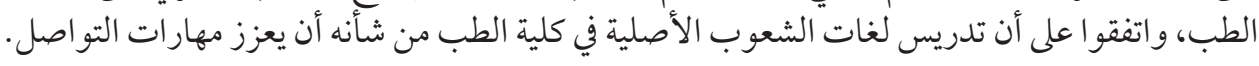

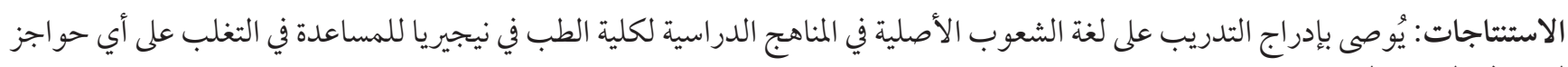

$$
\begin{aligned}
& \text { لغوية في الممارسة السريرية. }
\end{aligned}
$$

\section{References}

1. Hughes J. Why medical students should learn languages [internet]. Oslo: Keystone Academic Solutions; 2018 (https://www. healthcarestudies.com/article/why-medical-students-should-learn-languages/, accessed 12 May 2019).

2. Powell J. Overcoming language, cultural barriers in health care [internet]. Boston: Tufts Medical Center; 2016 (https://hhma.org/ blog/overcoming-language-cultural-barriers-in-health-care/, accessed 18 May 2019).

3. Burch V. Cultural competence or speaking the patient's language? Afr J Health Prof Educ. 2016;8(1):3. https://doi.org/10.7196/ AJHPE.2016.v8i1.802

4. Federal Ministry of Health; Consumer Protection Council. Patients' bill of rights. Abuja: Federal Ministry of Health; 2018 (http:// fccpc.gov.ng/uploads/files/patients-bill-of-rights-full-version.pdf, accessed 17 November 2019).

5. Harmsen JA, Bernsen RM, Bruijnzeels MA, Meeuwesen L. Patients' evaluation of quality of care in general practice: what are the cultural and linguistic barriers? Patient Educ Couns. 2008;72(1):155-62. https://doi.org/10.1016/j.pec.2008.03.018

6. Benson OV, Anyalebechi LI, Ariole IA. Promoting indigenous language in Nigeria: issues and challenges for the library and information professionals. Libr Philos Pract. 2017 (http://digitalcommons.unl.edu/libphilprac/1472, accessed 17 November 2019).

7. Schmuter G. Learning a second language: diversifying medical school from within. Acad Med. 2020;95(2);172. https://doi. org/10.1097/ACM.0000000000003070 
8. Alshareef M, Mobaireek O, Mohamud M, Alrajhi Z, Alhamdan A, Hamad B. Decision makers' perspectives on the language of instruction in medicine in Saudi Arabia: a qualitative study. Health Prof Educ. 2018;4(4):308-16. https://doi.org/10.1016/j. hpe.2018.03.006

9. Mohamed Z, Roche S, Claassen J, Jama Z. Students' perceptions of the effectiveness of additional language tuition in the University of Cape Town MBChB programme: a descriptive cross-sectional study. Afr J Prim Health Care Fam Med. 2019;11(1):e1-e10. https://doi.org/10.4102/phcfm.v11i1.2121

10. About Ekiti [internet]. Ado Ekiti: Ekiti State Government; 2021 (https://www.ekitistate.gov.ng/about-ekiti/\#population-figures, accessed 30 August 2021).

11. Abi Raad et al. Medical education in a foreign language and history-taking in the native language in Lebanon - a nationwide survey. BMC Med Educ. 2016;16(1):298. https://doi.org/10.1186/s12909-016-0826-7

12. Sabbour SM, Dewedar SA, Kandil SK. Language barriers in medical education and attitudes towards Arabization of medicine: student and staff perspectives. East Mediterr Health J. 2010;16(12):1263-71. https://doi.org/10.26719/2010.16.12.1263

13. Baker DW, Hayes R, Fortier JP. Interpreter use and satisfaction with interpersonal aspects of care for Spanish-speaking patients. Med Care. 1998;36(10):1461-70. 10.1097/00005650-199810000-00004

14. Aguilar M. Benefits of bilingual physicians [internet]. Los Angeles: David Geffen School of Medicine at UCLA; 2018 ((https:// medschool.ucla.edu/body.cfm?id=1158\&action=detail\&ref=752, accessed 12 May 2019).

15. The benefits of being bilingual in healthcare [internet]. Kent: Kent State University; 2017 (https://onlinedegrees.kent.edu/collegeof-public-health/public-health/community/benefits-bilingual-healthcare, accessed 9 February 2021). 